\title{
Phase stability and initial low-temperature oxidation mechanism of Ti2AIC thin films
}

\author{
Jenny Frodelius, Jun Lu, Jens Jensen, Dennis Paul, Lars Hultman and Per Eklund
}

\section{Linköping University Post Print}

N.B.: When citing this work, cite the original article.

Original Publication:

Jenny Frodelius, Jun Lu, Jens Jensen, Dennis Paul, Lars Hultman and Per Eklund, Phase stability and initial low-temperature oxidation mechanism of Ti2AlC thin films, 2013, Journal of the European Ceramic Society, (33), 2, 375-382.

http://dx.doi.org/10.1016/j.jeurceramsoc.2012.09.003

Copyright: Elsevier

http://www.elsevier.com/

Postprint available at: Linköping University Electronic Press

http://urn.kb.se/resolve?urn=urn:nbn:se:liu:diva-87955 


\title{
Phase stability and initial low-temperature oxidation mechanism of $\mathrm{Ti}_{2} \mathrm{AlC}$ thin films
}

\author{
Jenny Frodelius ${ }^{1)}$, Jun Lu ${ }^{1)}$, Jens Jensen ${ }^{1)}$, Dennis Paul ${ }^{2)}$, Lars Hultman ${ }^{1)}$, Per Eklund ${ }^{1 \text { )* }}$ \\ 1) Thin Film Physics Division, IFM, Linköping University, \\ 58183 Linköping, Sweden \\ 2) Physical Electronics USA, 18725 Lake Drive East \\ Chanhassen MN 55317, USA \\ *Corresponding author. Email: perek@,ifm.liu.se. Telephone +4613288940
}

\begin{abstract}
$\mathrm{Ti}_{2} \mathrm{AlC}$ thin films deposited onto $\mathrm{Al}_{2} \mathrm{O}_{3}$ by magnetron sputtering were used as model for studying the early stages $(<15 \mathrm{~min})$ of relatively-low-temperature $\left(500^{\circ} \mathrm{C}\right)$ oxidation of $\mathrm{Ti}_{2} \mathrm{AlC}$. The well-defined microstructure of these films forms a surface of valleys, hillocks and plateaus comprised of basal-plane-oriented grains with a fraction of nonbasal-planeoriented grains with out-of-plane orientation of (1013) and (1016) as shown by x-ray diffraction and $\mathrm{s}$ electron microscopy. During oxidation, $\mathrm{Al}_{2} \mathrm{O}_{3}$ clusters and areas of Ccontaining titania $\left(\mathrm{TiO}_{\mathrm{x}} \mathrm{C}_{\mathrm{y}}\right)$ are formed on the surface. A mechanism is proposed in which the locations of the $\mathrm{Al}_{2} \mathrm{O}_{3}$ clusters are related to the migration of $\mathrm{Al}$ atoms diffusing out of $\mathrm{Ti}_{2} \mathrm{AlC}$. The $\mathrm{Al}_{2} \mathrm{O}_{3}$ is initially formed in valleys or on plateaus where $\mathrm{Al}$ atoms have been trapped while $\mathrm{TiO}_{\mathrm{x}} \mathrm{C}_{\mathrm{y}}$ forms by in-diffusion of oxygen into the $\mathrm{Al}$-deficient $\mathrm{Ti}_{2} \mathrm{AlC}$.. At 500 ${ }^{\circ} \mathrm{C}$, the migration of $\mathrm{Al}$ atoms is faster than the oxidation kinetics; explaining this microstructure-dependent oxidation mechanism.
\end{abstract}

Keywords: Films; Electron microscopy; Carbides; Interfaces; Corrosion 


\section{Introduction}

$\mathrm{Ti}_{2} \mathrm{AlC}$ and $\mathrm{Ti}_{3} \mathrm{AlC}_{2}$ belong to a group of ternary hexagonal phases called $\mathrm{M}_{\mathrm{n}+1} \mathrm{AX}_{\mathrm{n}}$ phases $(\mathrm{n}=1,2$, or 3$)$ that consist of a transition metal $(\mathrm{M})$, an A-group element (A), and C and/or $\mathrm{N}(\mathrm{X})[1,2,3]$. In this system, there is also an intergrown phase, $\mathrm{Ti}_{5} \mathrm{Al}_{2} \mathrm{C}_{3}$, with alternating $\mathrm{Ti}_{2} \mathrm{AlC}$-like and $\mathrm{Ti}_{3} \mathrm{AlC}_{2}$-like stacking [4,5,6], a type of phase known in several MAX systems $[7,8,9,10]$, but $\mathrm{Ti}_{5} \mathrm{Al}_{2} \mathrm{C}_{3}$ is to date the only one synthesized in bulk with full structure determination [5]. $\mathrm{Ti}_{2} \mathrm{AlC}$ and $\mathrm{Ti}_{3} \mathrm{AlC}_{2}$ are promising materials for applications that demand stability at high temperatures and resistance against oxidation. Many oxidation studies of bulk $\mathrm{Ti}_{2} \mathrm{AlC}$ and $\mathrm{Ti}_{3} \mathrm{AlC}_{2}$ have focused on high temperature $\left(>1000{ }^{\circ} \mathrm{C}\right)$ oxidation over long periods of time (days) [11,12]. At these elevated temperatures, a protective $\alpha-\mathrm{Al}_{2} \mathrm{O}_{3}$ layer is formed on the surface $[13,14]$. The minimum temperature for formation of such a continuous protective layer is at least $700{ }^{\circ} \mathrm{C}$ [15]. During growth of the $\alpha-\mathrm{Al}_{2} \mathrm{O}_{3}$ layer, $\mathrm{TiO}_{2}$ forms on top of the $\mathrm{Al}_{2} \mathrm{O}_{3}$ scale as a result of Ti diffusion through the $\mathrm{Al}_{2} \mathrm{O}_{3}$ layer to the surface where it reacts with oxygen [16,17]. Once the $\alpha-\mathrm{Al}_{2} \mathrm{O}_{3}$ has grown to sufficient thickness, it will protect against further oxidation of the underlying $\mathrm{Ti}_{2} \mathrm{AlC}$ on the condition that the latter is sufficiently phase-pure $[18,19,20]$. Furthermore, $\mathrm{Ti}_{2} \mathrm{AlC}$ has a thermal expansion coefficient similar to $\mathrm{Al}_{2} \mathrm{O}_{3}$, an important fact that permits the material to be thermally cycled without spalling off the protective oxide [21].

Although the oxidation mechanisms of bulk $\mathrm{Ti}_{2} \mathrm{AlC}$ and $\mathrm{Ti}_{3} \mathrm{AlC}_{2}$ at high temperature and long oxidation times are well understood, the conditions during the initial oxidation stages are unclear. For fractured $\mathrm{Ti}_{3} \mathrm{AlC}_{2}$ surfaces with oxidation times of $20 \mathrm{~s}$ up to $15 \mathrm{~min}$ at $1100{ }^{\circ} \mathrm{C}$, Song et al. [22] described how $\alpha-\mathrm{Al}_{2} \mathrm{O}_{3}$ mainly forms on the basal planes and on 
the ledges to the fractured surfaces (also relevant for crack healing [23] and ultrahigh temperature ablation [24]). Oxidation at lower temperatures $\left(500-600{ }^{\circ} \mathrm{C}\right)$ is, however, different from that at high temperatures and tends to result in phase-mixed, porous, oxide layers with non-protective properties $[25,26]$. The phase purity is also an important factor to obtain good oxidation properties [27].

The purpose of this paper is to improve the understanding of the early stage of oxidation of $\mathrm{Ti}_{2} \mathrm{AlC}$ at low temperatures. The experiments are performed at $500{ }^{\circ} \mathrm{C}$ to remain well below the $700{ }^{\circ} \mathrm{C}$ at which a protective $\mathrm{Al}_{2} \mathrm{O}_{3}$ layer is formed, but simultaneously high enough to have appreciable oxidation kinetics. Short oxidation times $(5-15 \mathrm{~min})$ in ambient air are investigated to capture different oxidation stages using scanning electron microscopy and Auger nanoprobe. Magnetron sputtered thin films on single-crystal $\mathrm{Al}_{2} \mathrm{O}_{3}(0001)$ substrates are chosen as they form a well-defined model system for studying microstructural effects on oxidation.

\section{Experimental Details}

\subsection{Synthesis}

$\mathrm{Ti}_{2} \mathrm{AlC}$ thin films were deposited by magnetron sputtering at a substrate temperature of 770 ${ }^{\circ} \mathrm{C}$. A TiC seed layer was used to improve the crystal quality of $\mathrm{Ti}_{2} \mathrm{AlC}$ grown onto $\mathrm{Al}_{2} \mathrm{O}_{3}(0001)$. The substrates were cleaned in acetone and isopropanol in an ultrasonic bath and heat treated in-situ before deposition. The thin films were deposited from three circular 
elemental targets; a 3" Ti target, a 2" Al target and a 3" C target, operated in constant current mode. Deposition of TiC was made at a power density of $\sim 3.0 \mathrm{~W} / \mathrm{cm}^{2}$ for $\mathrm{Ti}$ and $\sim 5.6 \mathrm{~W} / \mathrm{cm}^{2}$ for $\mathrm{C}$. The power density for depositing $\mathrm{Ti}_{2} \mathrm{AlC}$ was kept at $\sim 2.8 \mathrm{~W} / \mathrm{cm}^{2}$ for Ti, $\sim 1.2 \mathrm{~W} / \mathrm{cm}^{2}$ for $\mathrm{Al}$, and $\sim 3.5 \mathrm{~W} / \mathrm{cm}^{2}$ for $\mathrm{C}$. All targets were facing the substrate from underneath where the $\mathrm{Al}$ target was mounted on axis while both $\mathrm{Ti}$ and $\mathrm{C}$ target was mounted with an off axis angle of $35^{\circ}$. More information about the setup can be found in Ref. 28. The vacuum chamber had a base pressure of $\sim 10^{-6} \mathrm{~Pa}\left(4 \cdot 10^{-8} \mathrm{mbar}\right)$ and the sputtering was performed with Ar gas (99.9999\%) at a pressure of $0.5 \mathrm{~Pa}$ (4 mTorr).

\subsection{Vacuum Annealing and Oxidation}

X-ray diffraction (XRD) measurements (Philips PW 1729) were performed in situ during annealing of thin films using a $\mathrm{CuK} \alpha$ radiation. Heating of the sample took place in a water cooled vacuum chamber with a base pressure of $10^{-3} \mathrm{~Pa}$. The samples were placed on a Ta filament surrounded by a second Ta filament. Both filaments were resistively heated and connected to $\mathrm{Pt} / \mathrm{Rh}$ thermocouples to monitor the temperature. The temperature was calibrated using a pure $\mathrm{Al}_{2} \mathrm{O}_{3}$ plate as reference to record the peak shifts with temperature [29]. One scan was made before annealing at ambient temperature. Then the heater was ramped with $\sim 50{ }^{\circ} \mathrm{C} / \mathrm{min}$ up to the desired temperature in the range of $300-900{ }^{\circ} \mathrm{C}$. A set of 3 scans (15 min each) was started 5 min after reaching the chosen temperature.

Two samples were oxidized in ambient air in a quartz-tube furnace at $500{ }^{\circ} \mathrm{C} \pm 5{ }^{\circ} \mathrm{C}$. The quartz tube containing a sample was not inserted in the oven until the temperature was 
stabilized. The temperature was measured with a thermocouple placed near the sample. When the quartz tube with the sample was inserted in the furnace, the sample reached a temperature of $500{ }^{\circ} \mathrm{C}$ after 12.5 min with ambient air present. After additional 5 or $15 \mathrm{~min}$ of oxidation in ambient air the quartz tube with the sample was taken out and cooled outside the furnace.

\subsection{Characterization}

The phase composition of the thin films was characterized by $\mathrm{x}$-ray diffraction (XRD) analysis (Philips PW 1729) with a line-focus $\mathrm{CuK}_{\alpha}$ source operating at $40 \mathrm{~mA}$ and $40 \mathrm{kV}$. Pole figure measurements were performed in an x-ray diffractometer (Philips X'Pert MRD) with a point focused $\mathrm{CuK}_{\alpha}$ source operating at $40 \mathrm{~mA}$ and $45 \mathrm{kV}$.

All scanning electron microscopy (SEM) images were performed (LEO 1550) with an SE2 secondary electron detector. The working distance was kept at $6 \mathrm{~mm}$ and the incoming electron beam at $2 \mathrm{keV}$. This low acceleration voltage was used to enhance the imaging of details on the surface.

Bright-field transmission electron microscopy (TEM) imaging was performed with a 200 $\mathrm{kV}$ field emission gun microscope (Tecnai G2 F20U-Twin). Cross-sectional samples were prepared using focused ion beam (FIB, Carl Zeiss CrossBeam 1540 EsB) with lift-out technique. The sample was cut out with Ga ions using an acceleration voltage of $30 \mathrm{keV}$, finishing off with $5 \mathrm{keV}$. 
Elemental surface mapping and localized sputter depth profiles were performed with a PHI 700Xi Scanning Auger Nanoprobe from Physical Electronics. The Auger spectra were obtained using a $10 \mathrm{keV}$ e-beam with a current of $10 \mathrm{nA}$ and beam size of $22 \mathrm{~nm}$. The sample was tilted $30^{\circ}$ with respect to the electron gun. The electron gun is located co-axial to the cylindrical mirror analyzer (CMA) minimizing shadowing effects caused by topography. Sputter profiling was achieved with a $500 \mathrm{eV}$ Ar ion beam hitting the sample at $42^{\circ}$ with respect to the surface normal. The sputter rate is roughly $2.5 \mathrm{~nm} /$ minute calibrated for $\mathrm{SiO}_{2}$.

\section{Results and Discussion}

\subsection{As-deposited thin films}

Figure 1 shows a typical $\mathrm{x}$-ray diffraction pattern of an as-deposited $\mathrm{Ti}_{2} \mathrm{AlC}$ thin film. The $\mathrm{Ti}_{2} \mathrm{AlC}(0001)$ planes are parallel with the substrate surface of $\mathrm{Al}_{2} \mathrm{O}_{3}(0001)$ as expected for the epitaxial growth mode [4]. The $\mathrm{Ti}_{2} \mathrm{AlC} 0006$ peak may be overlapped with 1013 (International Centre of Diffraction Data JCPDS 29-0095), since the $\mathrm{Ti}_{2} \mathrm{AlC} 1013$ and 0006 peaks are located close to each other at $2 \theta$ values of $39.5^{\circ}$ and $39.7^{\circ}$, respectively. The difference of $0.2^{\circ}$ is too small to be resolved by XRD. There is, however, a peak at $53.3^{\circ}$ (not shown in Figure 1) originating from 1016. The peak is small, as expected from the 
structure factor. Pole figure measurements of both 0002 and 1016 show no other orientations than what is observed from the $\theta / 2 \theta$ scan. The TiC 111 peak originates from the seed layer and pole figure measurements (not shown, essentially identical to Fig 1e in Ref. 30) show that the $\mathrm{TiC}$ is epitaxially grown onto the substrate with two sets of domains with three-fold symmetry.

In general, the growth of thin film MAX phases is dependent on the substrate temperature [1,31,32,33]. Substrate temperatures of $\sim 900{ }^{\circ} \mathrm{C}$ promote basal-plane-oriented $\mathrm{Ti}_{2} \mathrm{AlC}$ growth [4]. Lower temperatures, on the other hand, may result in nonbasal-oriented growth, even nearly perpendicular basal planes to the substrate surface, as has been observed for $\mathrm{Ti}_{2} \mathrm{AlN}$ [33] and $\mathrm{Cr}_{2} \mathrm{GeC}$ [34] (cf., also the discussion on growth and epitaxy in Refs. $[35,36])$. Figure 2 a) shows a SEM image of the top surface of an as-deposited $\mathrm{Ti}_{2} \mathrm{AlC}$ thin film. The main part of the surface is flat as a result of (0001) basal-plane-oriented epitaxial $\mathrm{Ti}_{2} \mathrm{AlC}$. In addition, the surface exhibits numerous nonbasal-plane-oriented grains including (1013) and (1016) (cf. Figure 1). At our substrate temperature of $770{ }^{\circ} \mathrm{C}$, it is likely that the basal plane growth does not result in full coverage due to the limited mobility of the ad-atoms. With increasing supersaturation at the reduced temperature, nucleation of nonbasal grain may occur. By virtue of their relatively fast growth, such grains will prevail. Figure 2 b) shows a higher magnification view of a typical flat area, which reveals the presence of basal-plane terraces. These form surface hillocks with hexagonal shapes characteristic of the crystal structure of $\mathrm{Ti}_{2} \mathrm{AlC}$. The way that the terraces of the basal planes have spread indicates that these areas have grown in Frank-van der Merwe (layer- 
by-layer) mode or possibly step-flow mode. The height of the terraces is in the direction of the c-axis and each terrace should therefore be a discrete number of unit cells [37]. Nonbasal-plane-oriented grains are evenly distributed and stand out from the basal-plane surface showing terraces from basal planes facing upwards. Most of these grains are elongated and are found in one out of three directions, often forming triangles as seen in Figure $2 \mathrm{~b}$ ). The long sides of the standing grains are aligned with the sides of the hexagonal hillocks. This indicates a three-fold symmetry relation between the standing grains and the $\mathrm{TiC}$ seed layer.

Figure 3 a) shows a cross-sectional TEM image of a nonbasal-plane-oriented $\mathrm{Ti}_{2} \mathrm{AlC}$ grain surrounded by basal $\mathrm{Ti}_{2} \mathrm{AlC}$ grains. The inset in Figure 3 a) is an electron diffraction pattern characteristic of MAX phases from the nonbasal-plane-oriented $\mathrm{Ti}_{2} \mathrm{AlC}$ grain [38]. The nonbasal-plane-oriented grain appears to have overgrown the basal grains and is $\sim 0.2 \mu \mathrm{m}$ higher from substrate to surface forming a plateau. This observation is not surprising, considering that the fastest growth direction for MAX-phases is along the basal planes [39], which in this case points upwards. The nonbasal-plane-oriented grain does not only grow upwards, but also downwards. The downward growth process consumes the seed layer and substrate by a topotactic reaction and creates a void between the grain and the substrate. Yet, the $\mathrm{Ti}_{2} \mathrm{AlC}$ film has no porosity except for the intersecting nonbasal grains (triangular pits in Fig. 2b). Growth of $\mathrm{Ti}_{2} \mathrm{AlC}$ into $\mathrm{Al}_{2} \mathrm{O}_{3}$ requires downwards diffusion of $\mathrm{Ti}$ and $\mathrm{C}$. The $\mathrm{Al}$ and $\mathrm{O}$ then presumably move upwards into the $\mathrm{Ti}_{2} \mathrm{AlC}$ grain where the oxygen can occupy $\mathrm{C}$ vacancies in the $\mathrm{Ti}_{2} \mathrm{AlC}$ crystal $[28,40]$. The possibility of a solid-state reaction between $\mathrm{TiC}$ and $\mathrm{Al}_{2} \mathrm{O}_{3}$ is well known $[4,28,40,41]$. Note that $\mathrm{O}$ has substantial solubility 
on $\mathrm{C}$ sites in $\mathrm{Ti}_{2} \mathrm{AlC}$ (perhaps as much as $25 \%$ [40]), but does not form a complete range of solid solutions like nitrogen does [42]. In contrast, the basal-plane-oriented $\mathrm{Ti}_{2} \mathrm{AlC}$ grains have a flat interface to the substrate and seem to have grown exclusively on top of the TiC seed layer. However, Figure $3 \mathrm{~b}$ ) is a cross sectional TEM image of the interfaces between the substrate, seed layer and $\mathrm{Ti}_{2} \mathrm{AlC}$ thin film which shows that the substrate and seed layer have reacted and formed extra layers of $\mathrm{Ti}_{2} \mathrm{AlC}$ with basal planes along the interface. This $\mathrm{Ti}_{2} \mathrm{AlC}$ may contain oxygen as well [4].

\subsection{Decomposition of $\mathrm{Ti}_{2} \mathrm{AlC}$ thin films}

In order to study what happens to the films during annealing in the absence of oxygen, in situ annealing of $\mathrm{Ti}_{2} \mathrm{AlC}$ thin films in vacuum was performed in the temperature range from ambient to $900{ }^{\circ} \mathrm{C}$. Table 1 shows the XRD intensity ratio of the $\mathrm{Ti}_{2} \mathrm{AlC} 0002$ and $\mathrm{TiC} 111$ peaks.

A constant value of the intensity ratio of 2.4 is observed up to $600{ }^{\circ} \mathrm{C}$. At $700{ }^{\circ} \mathrm{C}$, the ratio decreased to 1.85 and it continues to decrease with increasing temperature. At $900{ }^{\circ} \mathrm{C}$, neither $\mathrm{Ti}_{2} \mathrm{AlC} 0002$ nor $\mathrm{Ti}_{2} \mathrm{AlC} 0006 / 1013$ is present, while the TiC 111 peak is stronger than in the diffraction patterns at lower temperatures. These results show that initial decomposition of $\mathrm{Ti}_{2} \mathrm{AlC}$ in vacuum occurs at temperatures as low as $\sim 700{ }^{\circ} \mathrm{C}$, which is much lower than what has been reported for bulk material of $\mathrm{Ti}_{2} \mathrm{AlC}$ [43] and $\mathrm{Ti}_{3} \mathrm{AlC}_{2}$ [44]. The same difference has been observed for other MAX phases like $\mathrm{Ti}_{3} \mathrm{SiC}_{2}$ and $\mathrm{Cr}_{2} \mathrm{AlC}$ 
$[37,45]$. For instance, $\mathrm{Ti}_{3} \mathrm{SiC}_{2}$ thin films decompose at $1100{ }^{\circ} \mathrm{C}[37,46]$, which is lower than for bulk material. It is explained by the difference in detection sensitivity or chosen thickness criteria and also points out the role of the chemical environment. A parallel can be drawn to earlier oxidation studies of $\mathrm{Ti}_{2} \mathrm{AlC}$ where it has been found that to obtain a good oxidation resistance the material must be exposed to temperatures above $700{ }^{\circ} \mathrm{C}[15]$; to obtain sufficient $\mathrm{Al}$ mobility for enough $\mathrm{Al}$ to reach the surface and form a protective oxide layer.

\subsection{Oxidation of $\mathrm{Ti}_{2} \mathrm{AlC}$ thin films}

Figure 4 a) shows a SEM overview image of an oxidized $\mathrm{Ti}_{2} \mathrm{AlC}$ thin film top surface where the oxidation was performed at $500{ }^{\circ} \mathrm{C}$ in ambient air during 5 min. The image shows that the film has the same microstructure as before oxidation (c.f. Figure 2), except for the appearance of small round surface features with a diameter of the order of tens of nanometers. These round features have brighter contrast than the surrounding surface, which is likely caused by charging of a non-conductive material such as oxides. Furthermore, the round shape with no facets is expected for amorphous oxides [47], but $\gamma$ alumina cannot be excluded. As seen in Figure 4 a), these oxides are gathered in clusters on the surface. The clusters are mainly found at the bottom of the basal-plane terraces in "valleys" where several terraces meet as shown in Figure 4 b). Oxide clusters are also found on terraces surrounding the nonbasal-plane-oriented grains. The clusters are, however, not found on top of the hexagonal hillocks, as seen in Figure $4 \mathrm{c}$ ). 
Scanning auger nanoprobe was used to obtain well defined elemental surface mapping and depth profile measurements to identify the oxides and the results are presented in Figure 5). Figure 5 a) shows a SEM image of the chosen area of analysis. Figure 5 b) shows an overview of the $\mathrm{Ti}$ (green) and $\mathrm{Al}$ (red) distribution on the surface obtained by elemental surface mapping and Figure 5 c) shows depth profile measurements of spot 1, 2, and 3 labeled in Figure 5 a) and b). In general the results in Figure 5 a-c) confirm the presence of $\mathrm{Al}_{2} \mathrm{O}_{3}$ and C-containing Titania $\left(\mathrm{TiO}_{\mathrm{x}} \mathrm{C}_{\mathrm{y}}\right)$ on the surface. As seen in Figure 5 b) the flat areas are covered by either a mix of the oxides or only $\mathrm{TiO}_{\mathrm{x}} \mathrm{C}_{\mathrm{y}}$, while the nonbasal-oriented grains are covered by only $\mathrm{Al}_{2} \mathrm{O}_{3}$. The three depth profile spots represent these three distinct areas. Spot 1 is found on the flat surface and the elemental mapping (Figure $5 \mathrm{~b}$ ) show a top surface containing Ti. The depth profile measurement (Figure $5 \mathrm{c}$ ), shows that spot 1 has a relatively thick layer of $\mathrm{TiO}_{\mathrm{x}} \mathrm{C}_{\mathrm{y}}$ on top of the $\mathrm{Ti}_{2} \mathrm{AlC}$ with a thinner area of $\mathrm{Al}_{2} \mathrm{O}_{3}$ adjacent to the $\mathrm{Ti}_{2} \mathrm{AlC}$ interface. The $\mathrm{TiO}_{\mathrm{x}} \mathrm{C}_{\mathrm{y}}$ has been formed by the remains of $\mathrm{Ti}_{2} \mathrm{AlC}$ after the loss of $\mathrm{Al}$. The thick $\mathrm{TiO}_{\mathrm{x}} \mathrm{C}_{\mathrm{y}}$ oxide has been able to form since a lot of $\mathrm{Al}$ has been released instead of forming a protective $\mathrm{Al}_{2} \mathrm{O}_{3}$ scale on the surface. There are several patches similar to spot 1 on the flat surface and these areas are most likely represented by hillocks as presented in Figure 6. Spot 2 is also found on the flat surface but is covered by a mix of $\mathrm{Al}_{2} \mathrm{O}_{3}$ and $\mathrm{TiO}_{\mathrm{x}} \mathrm{C}_{\mathrm{y}}$, see Figure $5 \mathrm{~b}$ ), thus the oxide is not as thick as for spot 1. Spot 3 represent the nonbasal-oriented grains as seen in Figure 5 a), which has a top layer of $\mathrm{Al}_{2} \mathrm{O}_{3}$ on top of $\mathrm{TiO}_{\mathrm{x}} \mathrm{C}_{\mathrm{y}}$, see Figure $5 \mathrm{c}$ ).

We propose that the oxides seen in Figure 4 are dominated by $\mathrm{Al}_{2} \mathrm{O}_{3}$. To form clusters of $\mathrm{Al}_{2} \mathrm{O}_{3}$ at these specific areas on the surface, $\mathrm{Al}$ diffuses out of the crystal and migrates over 
the surface. It is known that the A element diffuses via the basal planes during decomposition of MAX phases $[1,2,37,48,49]$, since Al has a weaker bond to Ti compared to $\mathrm{C} . \mathrm{Al}$ is also predicted to have relatively low activation energy for migration in the crystal [50]. The release of Al usually occurs at elevated temperatures, but as demonstrated above, initial decomposition of $\mathrm{Ti}_{2} \mathrm{AlC}$ can occur already at $700{ }^{\circ} \mathrm{C}$ and possibly at even lower temperatures. A second driving force for Al to exit the crystal could be the presence of oxygen. Therefore, Al can diffuse out from the $\mathrm{Ti}_{2} \mathrm{AlC}$ crystal already at $500{ }^{\circ} \mathrm{C}$. However, the migration of $\mathrm{Al}$ appears to be faster at $500^{\circ} \mathrm{C}$ than the kinetics for oxidation, where the Al migrates on the surface in a liquid-like manner until it is trapped in the valleys, before it reacts with oxygen. In parallel, the $\mathrm{Al}$ vacancies formed in the $\mathrm{Ti}_{2} \mathrm{AlC}$ crystals enable oxygen in-diffusion, which promotes further oxidation to form $\mathrm{TiO}_{\mathrm{x}} \mathrm{C}_{\mathrm{y}}$ and maybe also $\mathrm{CO}_{2}(\mathrm{~g})$.

Based on the observations above, we infer that the oxidation mechanism of $\mathrm{Ti}_{2} \mathrm{AlC}$ in air at $500{ }^{\circ} \mathrm{C}$ proceeds as presented in Figure 6:

Step I: $\quad$ Out-diffusion of $\mathrm{Al}$ from $\mathrm{Ti}_{2} \mathrm{AlC}$ takes place preferentially along the crystal basal planes and the grain boundaries. The Al on the surface will not evaporate since the partial vapor pressure for $\mathrm{Al}$ is much lower than the chamber pressure at these temperatures.

Step II: $\quad$ Al moves along the terraces and gathers in the valleys or gets trapped on top of the nonbasal-oriented grains. 
Step III: Oxygen from the atmosphere reacts with the $\mathrm{Al}$ and forms amorphous $\mathrm{Al}_{2} \mathrm{O}_{3}$ rounded mounds with size in the tens of nanometer range.

Step IV: When the oxidation process continues, the $\mathrm{Ti}_{2} \mathrm{AlC}$ crystal keeps releasing $\mathrm{Al}$, which continues to fill the valleys and oxidizes.

Figure 7 shows a SEM image of a $\mathrm{Ti}_{2} \mathrm{AlC}$ thin film surface oxidized in ambient air at 500 ${ }^{\circ} \mathrm{C}$ for 15 min (i.e. Step $I V$ ). There are continuous oxide layers covering areas of a width of micrometers in contrast to the small round features as seen for the thin film oxidized for 5 min (c.f. Figure 4). The oxide covers valleys of the original terrace surface and surrounds the nonbasal-plane-oriented grains. This shows that, with time, the oxide formed in the valleys becomes both thicker and spreads out over the $\mathrm{Ti}_{2} \mathrm{AlC}$ basal plane surface.

To place these results in relation with known oxidation mechanisms for $\mathrm{Ti}_{2} \mathrm{AlC}$ and $\mathrm{Ti}_{3} \mathrm{AlC}_{2}$ we compare with earlier studies on bulk material. We have observed that during oxidation of $\mathrm{Ti}_{2} \mathrm{AlC}$ at lower temperature of $500{ }^{\circ} \mathrm{C}$, clusters of $\mathrm{Al}_{2} \mathrm{O}_{3}$ are first formed, followed by the formation of $\mathrm{TiO}_{\mathrm{x}} \mathrm{C}_{\mathrm{y}}$. However, oxidation studies of bulk $\mathrm{Ti}_{2} \mathrm{AlC}$ and $\mathrm{Ti}_{3} \mathrm{AlC}_{2}$ at $500{ }^{\circ} \mathrm{C}$ for 20 min or longer show how a $\mathrm{TiO}_{2}$ scale (anatase and rutile) form, and that if any $\mathrm{Al}_{2} \mathrm{O}_{3}$ exists it is expected to be amorphous $[25,26]$. This means that with time the $\mathrm{TiO}_{2}$ will be dominant and form a scale on the cost of the formation of $\mathrm{Al}_{2} \mathrm{O}_{3}$.

Oxidation of $\mathrm{Ti}_{2} \mathrm{AlC}$ and $\mathrm{Ti}_{3} \mathrm{AlC}_{2} \geq 1000{ }^{\circ} \mathrm{C}$ has a different outcome. Initial oxidation of $\mathrm{Ti}_{3} \mathrm{AlC}_{2}$ at $1100{ }^{\circ} \mathrm{C}$ results in string-like oxides, assumed to grow along the $\mathrm{Al}$ atom planes 
of fractured surfaces [22]. One explanation why lower temperatures results in oxide clusters and higher temperatures in string-like oxides is that lower temperature decreases the kinetics of the oxidation reaction and therefore the $\mathrm{Al}$ have time to migrate over the surface before reacting with oxygen, while higher temperature leads to an instant formation of oxides as the $\mathrm{Al}$ reaches the surface.

Longer oxidation time at temperatures $\geq 1000^{\circ} \mathrm{C}$ results in a dense protective crystalline $\alpha$ $\mathrm{Al}_{2} \mathrm{O}_{3}$ scale on top of the $\mathrm{Ti}_{2} \mathrm{AlC}$ surface [19]. $\mathrm{TiO}_{2}$ is instead formed as an outer layer on top of the $\mathrm{Al}_{2} \mathrm{O}_{3}$ scale as Ti diffuse out through the underlying $\mathrm{Al}_{2} \mathrm{O}_{3}$ to react with oxygen [19]. Our annealing results explain the difference between the oxide scales of low and high oxidation temperature. A temperature above $700{ }^{\circ} \mathrm{C}$ is beneficial for the material to release sufficient amounts of $\mathrm{Al}$ fast enough so that a covering scale of $\mathrm{Al}_{2} \mathrm{O}_{3}$ can form. Below 700 ${ }^{\circ} \mathrm{C}$ the competition between the two oxides is finally won by $\mathrm{TiO}_{2}$.

\section{Conclusions}

$\mathrm{Ti}_{2} \mathrm{AlC}$ thin films have been used as a model for studying the early stages of oxidation at a relatively low temperature of $500{ }^{\circ} \mathrm{C}$. The thin films have a well defined microstructure of crystalline grains which forms a surface of valleys, hillocks and plateaus. Thus, they constitute an ideal model system for investigating microstructure-dependent oxidation.

During oxidation clusters of $\mathrm{Al}_{2} \mathrm{O}_{3}$, and C-containing titania $\left(\mathrm{TiO}_{\mathrm{x}} \mathrm{C}_{\mathrm{y}}\right)$ are formed on the surface. It is found that the positions of the $\mathrm{Al}_{2} \mathrm{O}_{3}$ clusters are related to the migration of the 
$\mathrm{Al}$ atoms that diffuses out from the $\mathrm{Ti}_{2} \mathrm{AlC}$ crystals. The $\mathrm{Al}_{2} \mathrm{O}_{3}$ is initially formed in the valleys or on the plateaus where the Al-atoms have been trapped while the $\mathrm{TiO}_{\mathrm{x}} \mathrm{C}_{\mathrm{y}}$ forms by in-diffusion of oxygen into the $\mathrm{Al}$ vacancies of the $\mathrm{Ti}_{2} \mathrm{AlC}$ crystal. At $500{ }^{\circ} \mathrm{C}$ the migration of $\mathrm{Al}$ atoms is faster than the formation of $\mathrm{Al}_{2} \mathrm{O}_{3}$ (low kinetics) and therefore it is possible for $\mathrm{TiO}_{\mathrm{x}} \mathrm{C}_{\mathrm{y}}$ to form as well. A combination of $\mathrm{Al}_{2} \mathrm{O}_{3}$ and $\mathrm{TiO}_{\mathrm{x}} \mathrm{C}_{\mathrm{y}}$ is not beneficial for obtaining a resistance against further oxidation of the material. It is found that the release of $\mathrm{Al}$ from $\mathrm{Ti}_{2} \mathrm{AlC}$ is most effective at temperatures $\geq 700{ }^{\circ} \mathrm{C}$. A higher rate of out-diffusion of $\mathrm{Al}$ to the surface makes it apt to form a covering protective $\mathrm{Al}_{2} \mathrm{O}_{3}$ scale, and therefore $\mathrm{Ti}_{2} \mathrm{AlC}$ requires an oxidation temperature $\geq 700^{\circ} \mathrm{C}$ to obtain a good oxidation resistance.

\section{Acknowledgments}

N. Ghafoor and P.O.A Persson at Thin Film Physics (Linköping University) are acknowledged for assistance with TEM. The Swedish National Graduate School in Materials Science is acknowledged for financial support. 


\section{References}

[1] Eklund P, Beckers M, Jansson U, Högberg H, Hultman L. The $\mathrm{M}_{\mathrm{n}+1} \mathrm{AX}_{\mathrm{n}}$ phases: materials science and thin film processing. Thin Solid Films 2010;518:1851-78.

[2] Wang JY, Zhou YC. Recent progress in theoretical prediction, preparation, and characterization of layered ternary transition-metal carbides. Annu Rev Mater Res 2009;39:415-43.

[3] Barsoum MW. The $\mathrm{M}_{\mathrm{N}+1} \mathrm{AX} X_{\mathrm{N}}$ Phases: A New Class of Solids; Thermodynamically Stable Nanolaminates. Prog Solid State Chem 2000;28;201-81.

[4] Wilhelmsson O, Palmquist J-P, Lewin E, Emmerlich J, Eklund P, Persson POÅ, Högberg H, Li S, Ahuja R, Eriksson O, Hultman L, Jansson U. Deposition of ternary thin films within the Ti-Al-C System by dc Magnetron Sputtering. J Cryst Growth 2006;291:290-300.

[5] Lane NJ, Naguib M, Lu J, Hultman L, Barsoum MW. Structure of a new bulk $\mathrm{Ti}_{5} \mathrm{Al}_{2} \mathrm{C}_{3}$ MAX phase produced by the topotactic transformation of $\mathrm{Ti}_{2} \mathrm{AlC}$. J Eur Ceram Soc 2012;32: 3485-91.

[6] Lane NJ, Naguib M, Lu J, Eklund P, Hultman L, Barsoum MW. Comment on " $\mathrm{Ti}_{5} \mathrm{Al}_{2} \mathrm{C}_{3}$ : A New Ternary Carbide Belonging to MAX Phases in the Ti-Al-C System". J Am Ceram Soc 2012, DOI: 10.1111/j.1551-2916.2012.05299.x (2012).

[7] Palmquist JP, Li S, Persson POÅ, Emmerlich J, Wilhelmsson O, Högberg H, Katsnelson MI, Johansson B, Ahuja R, Eriksson O, Hultman L, Jansson U. $\mathrm{M}_{\mathrm{n}+1} \mathrm{AX} \mathrm{n}_{\mathrm{n}}$ phases in the Ti-Si-C system studied by thinfilm synthesis and ab initio calculations. Phys Rev B 2004;70:165401.

[8] Högberg H, Eklund P, Emmerlich J, Birch J, Hultman L. Epitaxial $\mathrm{Ti}_{2} \mathrm{GeC}, \mathrm{Ti}_{3} \mathrm{GeC}_{2}$, and $\mathrm{Ti}_{4} \mathrm{GeC}_{3} \mathrm{MAX}-$ phase thin films grown by magnetron sputtering. $J$ Mater Res 2005;20:779-82.

[9] Högberg H, Hultman L, Emmerlich J, Joelsson T, Eklund P, Molina-Aldareguia JM, Palmquist JP, Wilhelmsson O, Jansson U. Growth and characterization of MAX-phase thin films. Surf Coat Technol 2005;193:6-10.

[10] Scabarozi TH, Hettinger JD, Lofland SE, Lu J, Hultman L, Jensen J, Eklund P. Epitaxial growth and electrical-transport properties of $\mathrm{Ti}_{7} \mathrm{Si}_{2} \mathrm{C}_{5}$ thin films synthesized by reactive sputter-deposition. 
Scripta Mater 2011;65:811-14.

[11] Wang XH, Zhou YC. Layered Machinable and Electrically Conductive $\mathrm{Ti}_{2} \mathrm{AlC}$ and $\mathrm{Ti}_{3} \mathrm{AlC}_{2}$ Ceramics: a Review. J Mater Sci Technol 2010;26:385-416.

[12] Wang XH, Li FZ, Chen JX, Zhou YC. Insights into high temperature oxidation of $\mathrm{Al}_{2} \mathrm{O}_{3}$-forming $\mathrm{Ti}_{3} \mathrm{AlC}_{2}$. Corr Sci 2012;58:95-103.

[13] Wang XH, Zhou YC. Oxidation behavior of $\mathrm{Ti}_{3} \mathrm{AlC}_{2}$ at $1000-1400{ }^{\circ} \mathrm{C}$ in air. Corros Sci 2003;45:891-907.

[14] Yang HJ, Pei YT, Song GM, De Hosson JThM. Comments on “microstructural evolution during hightemperature oxidation of $\mathrm{Ti}_{2} \mathrm{AlC}$ ceramics". Scripta Mater 2011;65:930-32.

[15] Sonestedt M, Frodelius J, Sundberg M, Hultman L, Stiller K. Oxidation of $\mathrm{Ti}_{2} \mathrm{AlC}$ bulk and spray deposited coatings. Corros Sci 2010;52:3955-3961.

[16] Yang HJ, Pei YT, Rao JC, de Hosson JThM, Li SB, Song GM. High temperature healing of Ti ${ }_{2} \mathrm{AlC}$ : On the origin of inhomogeneous oxide scale. Scripta Mater 2011;65:135-38.

[17] Rao JC, Pei YT, Yang HJ, Song GM, Li SB, de Hosson JThM. TEM study of the initial oxide scales of $\mathrm{Ti}_{2} \mathrm{AlC}$. Acta Mater 2011;59:5216-5223.

[18] Lee DB, Park SW. High-temperature oxidation of $\mathrm{Ti}_{3} \mathrm{AlC}_{2}$ between 1173 and $1473 \mathrm{~K}$ in air. Mater Sci Eng A 2006;434:147-154.

[19] Wang XH, Zhou YC. High-Temperature Oxidation Behavior of $\mathrm{Ti}_{2} \mathrm{AlC}$ in Air. Oxid. Met. 2003;59:303-320.

[20] Byeon J, Liu J, Hopkins M, Fischer W, Garimella N, Park KB, Brady MP, Radovic M, El-Raghy T, Sohn YH. Microstructure and Residual Stress of Alumina Scale Formed on $\mathrm{Ti}_{2} \mathrm{AlC}$ at High Temperature in Air. Oxid Met 2007;68:97-111.

[21] Sundberg M, Malmqvist G, Magnusson A, El-Raghy T. Alumina forming high temperature silicides and carbides. Ceram Int 2004;30:1899-1904.

[22] Song GM, Pei YT, Sloof WG, Li SB, de Hosson JThM, van der Zwaag S. Early stages of oxidation of $\mathrm{Ti}_{3} \mathrm{AlC}_{2}$ ceramics. Mater Chem Phys 2008;112:762-8. 
[23] Li SB, Song GM, Kwakernaak K, van der Zwaag S, Sloof WG. Multiple crack healing of a $\mathrm{Ti}_{2} \mathrm{AlC}$ ceramic. J Eur Ceram Soc 2012;32:1813-20.

[24] Song GM, Li SB, Zhao CX, Sloof WG, van der Zwaag S, Pei YT, de Hosson JThM. Ultra-high temperature ablation behavior of Ti2AlC ceramics under an oxyacetylene flame. J Eur Ceram Soc 2011;31:855-62.

[25] Wang XH, Zhou YC. Intermediate-temperature Oxidation Behaviour of Ti2AlC in Air. J Mater Res 2002;17:2974-81.

[26] Wang XH, Zhou YC. Improvement of intermediate-temperature oxidation resistance of Ti3AlC2 by preoxidation. Mat Res Innovat 2003;7:381-90.

[27] Wang QM, Garkas W, Flores Renteria A, Leyens C, Lee HW, Kim KH. Oxidation behaviour of Ti-Al-C films composed mainly of a Ti2AlC phase. Corros Sci 2011;53:2948-55.

[28] Frodelius J, Eklund P, Beckers M, Persson POÅ, Högberg H, Hultman L. Sputter-deposition from a $\mathrm{Ti}_{2} \mathrm{AlC}$ target: Process characterization and conditions for growth of $\mathrm{Ti}_{2} \mathrm{AlC}$. Thin Solid Films 2010;518:1621-26.

[29] Reeber RR, Wang K. Lattice Parameters and Thermal Expansion of Important Semiconductors and Their Substrates. Mater. Res. Soc. Symp., 2000;622:T6.35.1-6.

[30] Eklund P, Högberg H, Hultman L. Epitaxial TiC/SiC multilayers. Phys Stat Sol RRL 2007;1:113-5.

[31] Walter C, Sigumonrong D, El-Raghy T, Schneider JM. Towards large area deposition of $\mathrm{Cr}_{2} \mathrm{AlC}$ on steel. Thin Solid Films 2006;515:389-93.

[32] Li JJ, Hu LF, Li FZ, Li MS, Zhou YC. Variation of microstructure and composition of the $\mathrm{Cr}_{2} \mathrm{AlC}$ coating prepared by sputtering at 370 and $500{ }^{\circ}$ C. Surf Coat Technol 2010;204:3838-45.

[33] Beckers M, Höglund C, Baehtz C, Martins RMS, Persson POÅ, Hultman L, Möller W. The influence of substrate temperature and Al mobility on the microstructural evolution of magnetron sputtered ternary Ti-Al-N thin films.J Appl Phys 2009;106:064915.

[34] Eklund P, Bugnet M, Mauchamp V, Dubois S, Tromas C, Jensen J, Piraux L, Gence L, Jaouen M, Cabioc'h T. Epitaxial growth and electrical transport properties of $\mathrm{Cr}_{2} \mathrm{GeC}$ thin films. 
Phys Rev B 2011;84:075424.

[35] Tucker MD, Persson POÅ, Guenette MC, Rosén J, Bilek MMM, McKenzie D. Substrate orientation effects on the nucleation and growth of the $\mathrm{M}_{n+1} \mathrm{AX}_{n}$ phase $\mathrm{Ti}_{2} \mathrm{AlC}$. J Appl Phys 2011;109:014903.

[36] Eklund P, Murugaiah A, Emmerlich J, Csigany Z, Frodelius J, Barsoum MW, Högberg H, Hultman L. Homoepitaxial growth of Ti-Si-C MAX-phase thin films on bulk $\mathrm{Ti}_{3} \mathrm{SiC}_{2}$ substrates J Cryst Growth 2007;304:264-9.

[37] Emmerlich J, Music D, Eklund P, Wilhelmsson O, Jansson U, Schneider JM, Högberg H, Hultman L. Thermal stability of $\mathrm{Ti}_{3} \mathrm{SiC}_{2}$ thin films. Acta Mater 2007;55:1479-88.

[38] Lin ZJ, Zhuo MJ, Zhou YC, Li MS, Wang JY. Microstructural characterization of layered ternary $\mathrm{Ti}_{2} \mathrm{AlC}$. Acta Mater 2006;54:1009-15.

[39] Zhou YC, Dong HY, Yu BH. Development of titanium tin carbide (Ti2SnC) plate based on the electronic structure investigation. Mater Res Innovat 2000;4:36-41.

[40] Persson POÅ, Rosén J, McKenzie DR, Bilek MMM. Formation of the MAX-phase oxycarbide $\mathrm{Ti}_{2} \mathrm{AlC}_{1-\mathrm{x}} \mathrm{O}_{\mathrm{x}}$ studied via electron energy-loss spectroscopy and first-principles calculations. Phys Rev B 2009;80:092102.

[41] Persson POA, Rosen J, McKenzie DR, Bilek MMM, Hoglund C. A solid phase reaction between $\mathrm{TiC}_{\mathrm{x}}$ thin films and $\mathrm{Al}_{2} \mathrm{O}_{3}$ substrates. $J$ Appl Phys 2008;103:066102.

[42] Cabioc'h T, Eklund P, Mauchamp V, Jaouen M. Structural investigation of substoichiometry and solid solution effects in $\mathrm{Ti}_{2} \mathrm{Al}\left(\mathrm{C}_{\mathrm{x}}, \mathrm{N}_{1-\mathrm{x}}\right)_{\mathrm{y}}$ compounds. J Eur Ceram Soc 2012;32:1803-11.

[43] Pang WK, Low IM. Diffraction Study of Thermal Dissociation in the Ternary Ti-Al-C System. J Aust Ceram Soc 2009;45:30-33.

[44] Wang XH, Zhou YC. Stability and selective oxidation of aluminum in nanolaminate $\mathrm{Ti}_{3} \mathrm{AlC}_{2}$ upon heating in argon. Chem Mater 2003;15:3716-20.

[45] Wang QM, Flores Renteria A, Schroeter O, Mykhaylonka R, Leyens C, Garkas W, to Baben M. Fabrication and oxidation behavior of $\mathrm{Cr} 2 \mathrm{AlC}$ coating on Ti6242 alloy. 
Surf Coat Technol 2010;204:2343-52.

[46] Eklund P, Virojanadara C, Emmerlich J, Johansson LI, Högberg H, Hultman L.

Photoemission studies of $\mathrm{Ti}_{3} \mathrm{SiC}_{2}$ and nc-TiC/a-SiC nanocomposite thin films.

Phys Rev B 2006;74:045417.

[47].Jeurgens LPH, Sloof WG, Tichelaar FD, Mittemeijer EJ. Growth kinetics and mechanisms of aluminumoxide films formed by thermal oxidation of aluminum. $J$ Appl Phys 2002;92:1649-56.

[48] Emmerlich J, Eklund P, Rittrich D, Högberg H, Hultman L.

Electrical resistivity of $\mathrm{Ti}_{\mathrm{n}+1} \mathrm{AC}_{\mathrm{n}}(\mathrm{A}: \mathrm{Si}, \mathrm{Ge}, \mathrm{Sn})$ thin films. J Mater Res 2007;22:2279-87.

[49] Frodelius J, Johansson E, Cordoba Gallego JM, Odén M, Eklund P, Hultman L.

Annealing of thermally sprayed $\mathrm{Ti}_{2} \mathrm{AlC}$ coatings. Int J Appl Ceram Technol 2011;8:74-84.

[50] Music D, Riley DP, Schneider JM. Energetics of point defects in TiC. J Eur Ceram Soc 2009;29:773-7. 


\section{Table}

Table 1. Ratio between x-ray diffraction peaks acquired during in-situ measurements of a $\mathrm{Ti}_{2} \mathrm{AlC}$ film on a TiC seed layer annealed in vacuum.

$\begin{array}{lc}\text { Temperature }\left({ }^{\circ} \mathrm{C}\right) & \operatorname{Ti}_{2} \underline{A l C}(0002) / \operatorname{TiC}(111) \\ \text { Ambient } & 2.42 \\ 300 & 2.43 \\ 500 & 2.40 \\ 600 & 2.42 \\ 650 & 2.33 \\ 700 & 1.85 \\ 750 & 1.22 \\ 800 & 0.70 \\ 850 & 0.33\end{array}$




\section{Figure captions}

Figure 1. X-ray diffractogram of a Ti ${ }_{2} \mathrm{AlC}$ thin film with a TiC seed layer deposited onto a single crystalline $\mathrm{Al}_{2} \mathrm{O}_{3}(0001)$ substrate.

Figure 2. SEM images of the top surface of a Ti $i_{2}$ AlC thin film where a) shows an overview, and b) hexagonal shaped hillocks and triangles.

Figure 3 a). Bright-field TEM cross-sectional image of a Ti $i_{2} A l C$ grain showing how the basal planes are standing up from the $\mathrm{Al}_{2} \mathrm{O}_{3}$ substrate surface and spreads out over the surrounding epitaxially grown $\mathrm{Ti}_{2}$ AlC grains. The inset is a diffraction pattern from the standing grain. b). Interface between substrate $\left(\mathrm{Al}_{2} \mathrm{O}_{3}\right)$, seed layer (TiC) and $\mathrm{Ti}_{2} \mathrm{AlC}$ showing reaction between substrate and seed layer resulting in the formation of an interfacial layer of $\mathrm{Ti}_{2} \mathrm{AlC}$.

Figure 4. SEM image of an Ti $i_{2} \mathrm{AlC}$ thin film oxidized in ambient air at $500{ }^{\circ} \mathrm{C}$ for 5 min showing a) overview, b) oxide clusters, and c) hexagonal shaped hillock free of the oxide clusters.

Figure 5. a) SEM-image overview of an area on the $\mathrm{Ti}_{2} \mathrm{AlC}$ thin film oxidized in ambient air at $500{ }^{\circ} \mathrm{C}$ for 5 min measured with scanning auger nanoprobe b) distribution of Ti (green) and Al (red) and depth profiles from c) spot 1, d) spot 2, and e) spot 3 marked in the SEM image.. 
Figure 6. Illustration of the initial oxidation mechanism of $T i_{2} A l C$ thin films in ambient air at $500{ }^{\circ} \mathrm{C}$. Al leaves the $\mathrm{Ti}_{2} \mathrm{AlC}$ crystal via the basal planes (Step I), migrates down the terraces where it gathers in the valleys (Step II), and reacts with oxygen to form amorphous $\mathrm{Al}_{2} \mathrm{O}_{3}$ (Step III). With time, the oxide grows thicker and spreads out over the terraces (Step $I V)$.

Figure 7. SEM image of a Ti, AlC thin film surface oxidized in ambient air at $500^{\circ}$ for $15 \min$. 


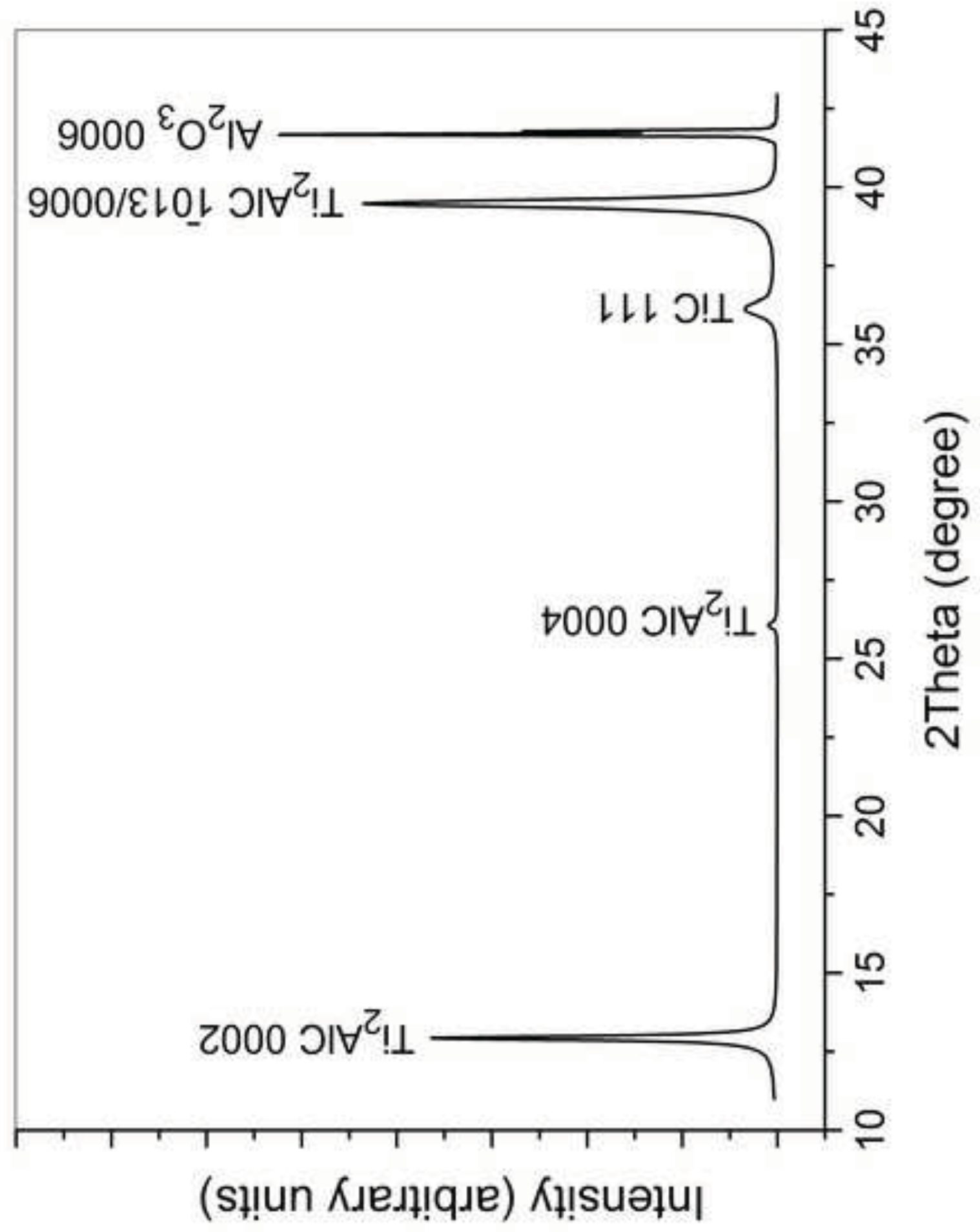




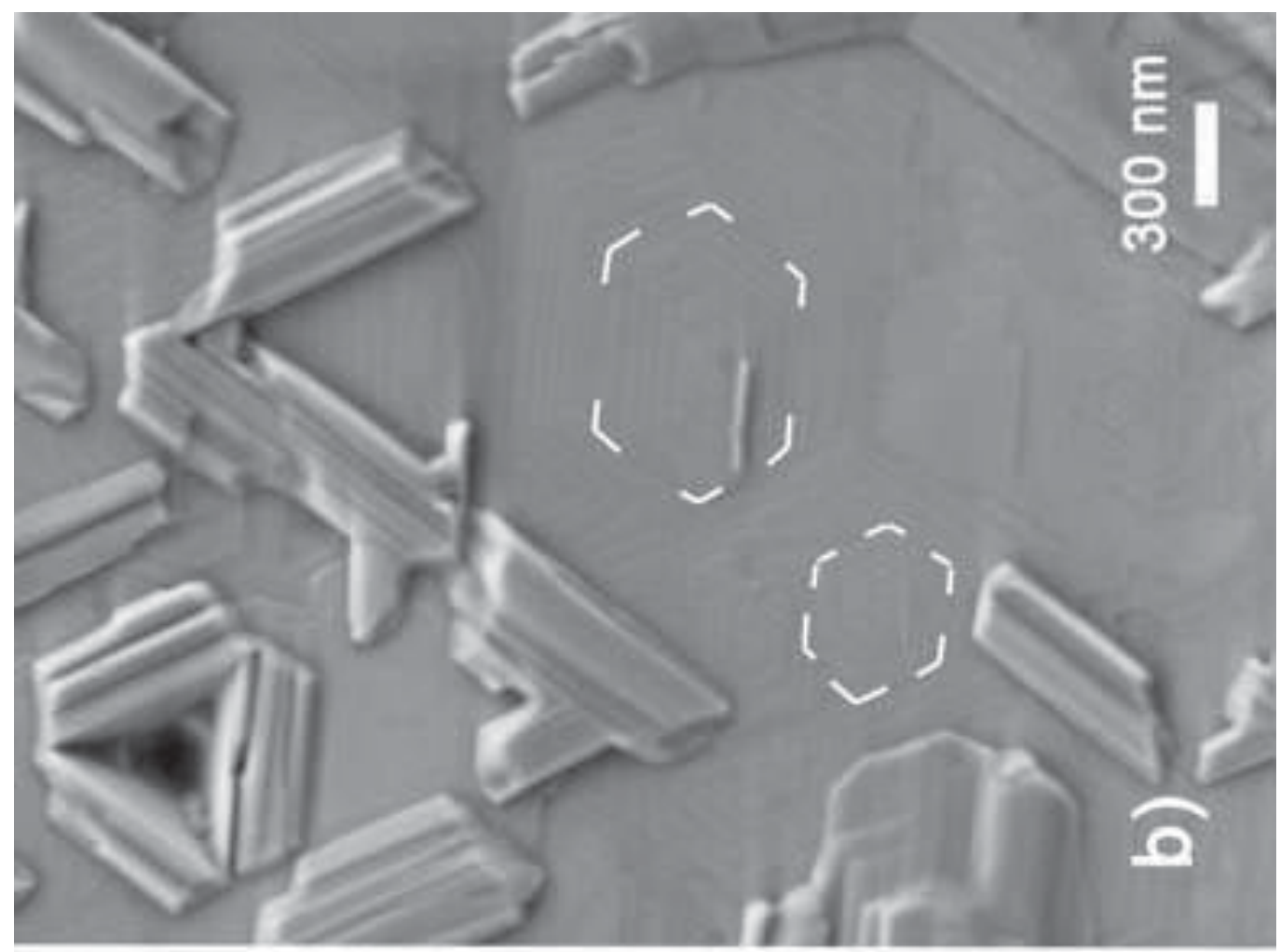

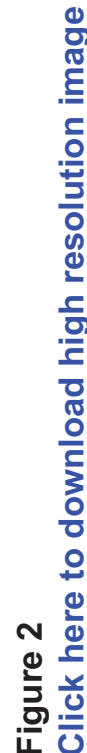

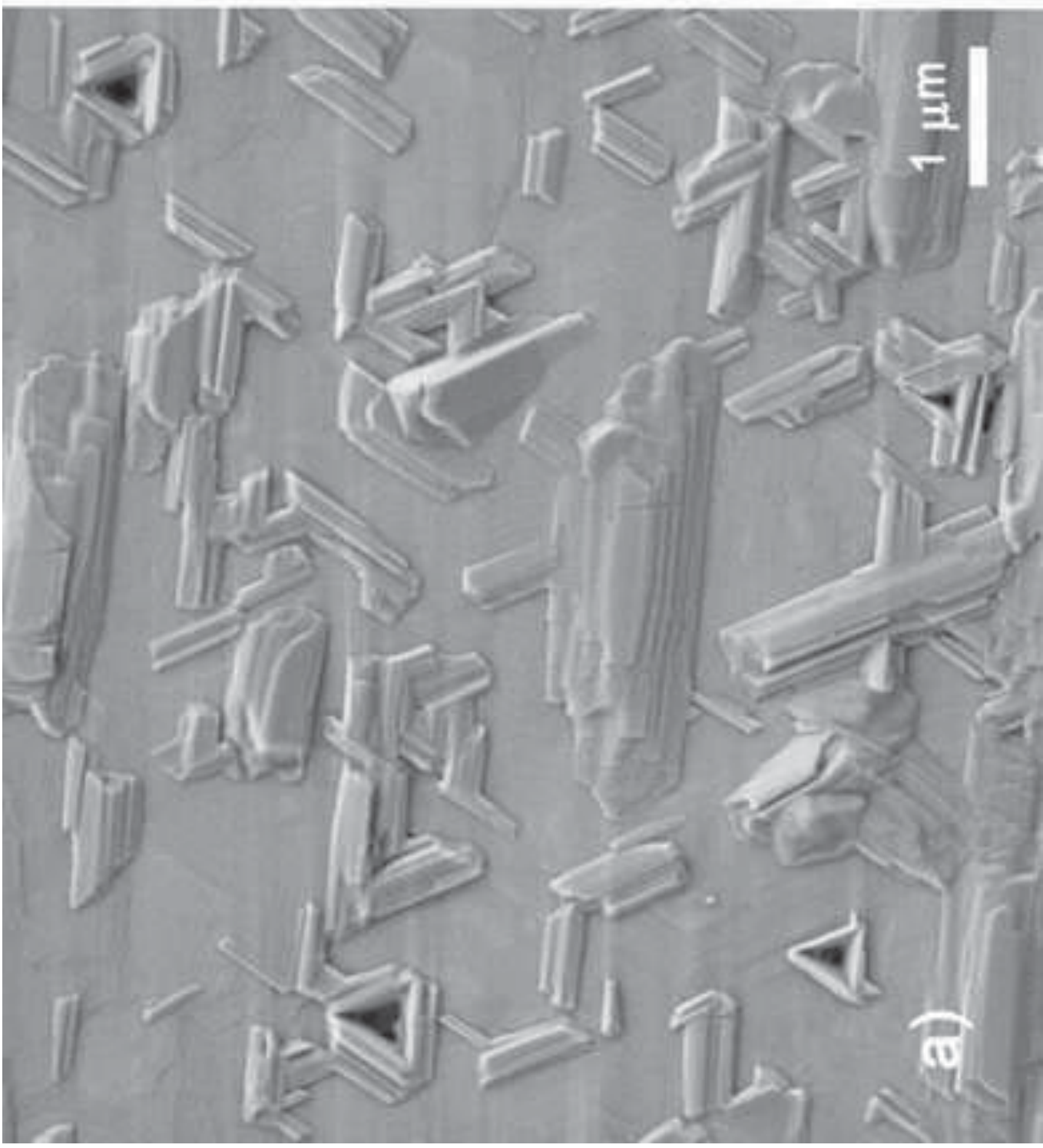


Click here to download high resolution image
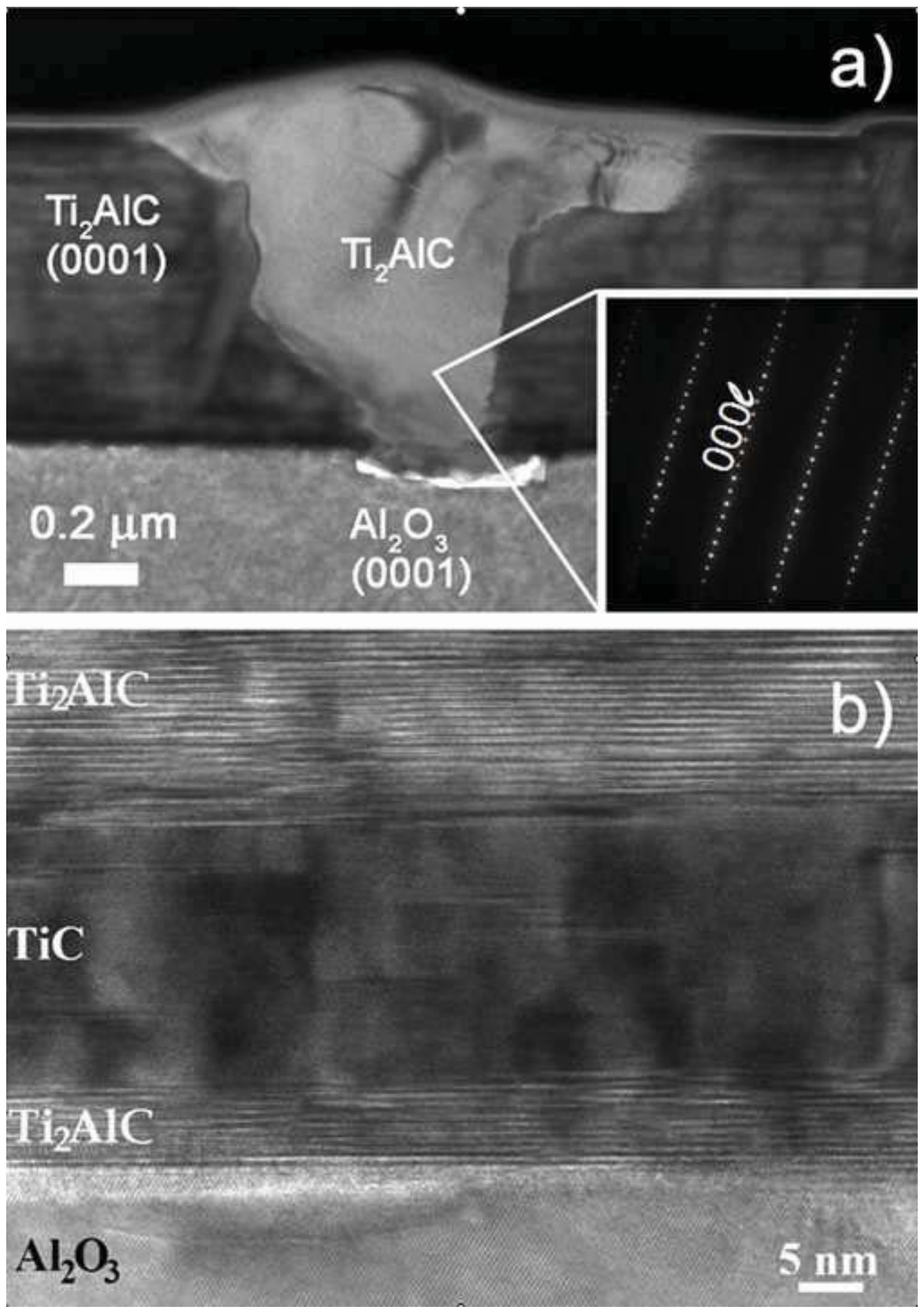


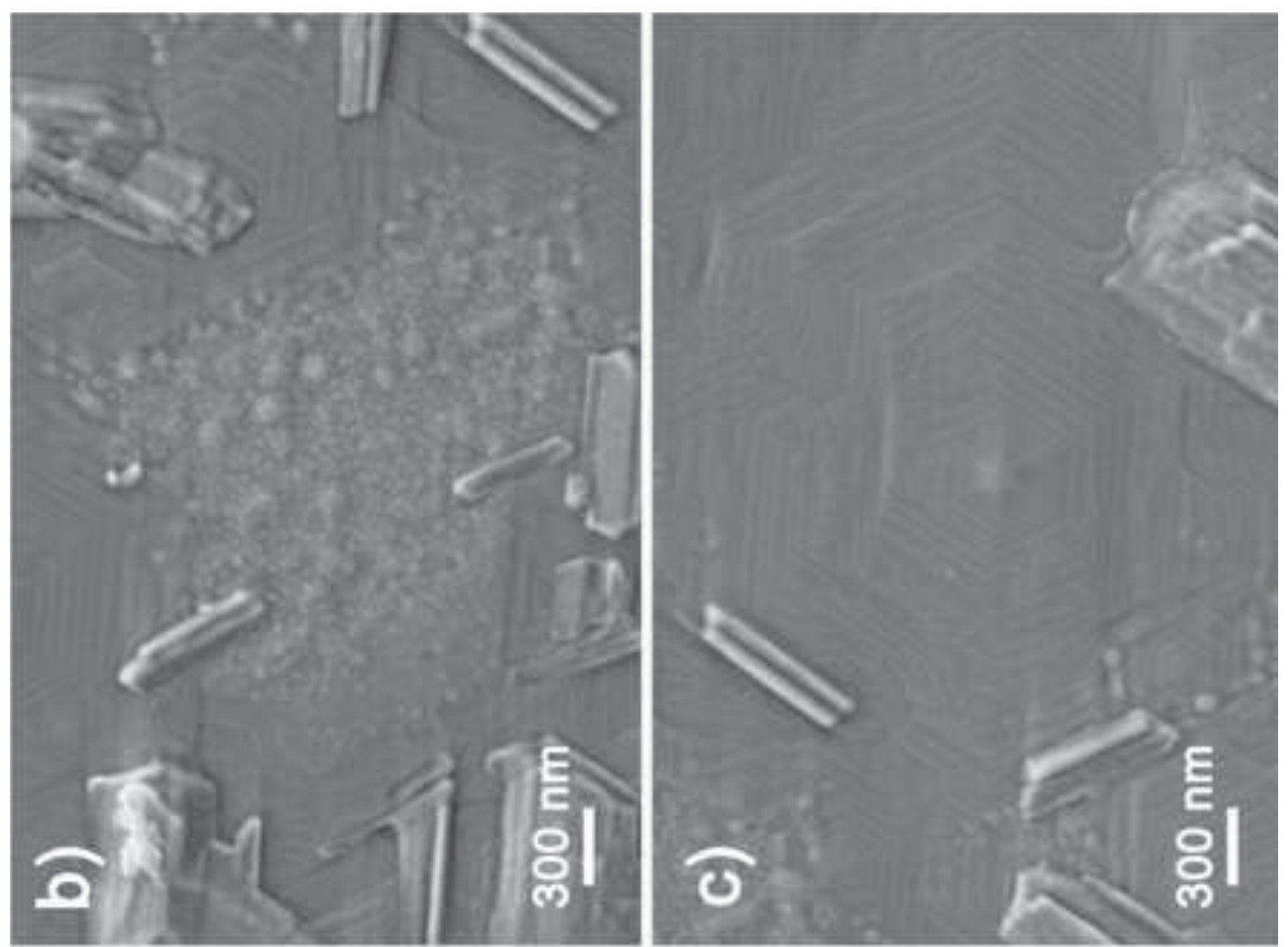

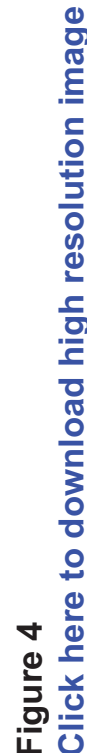

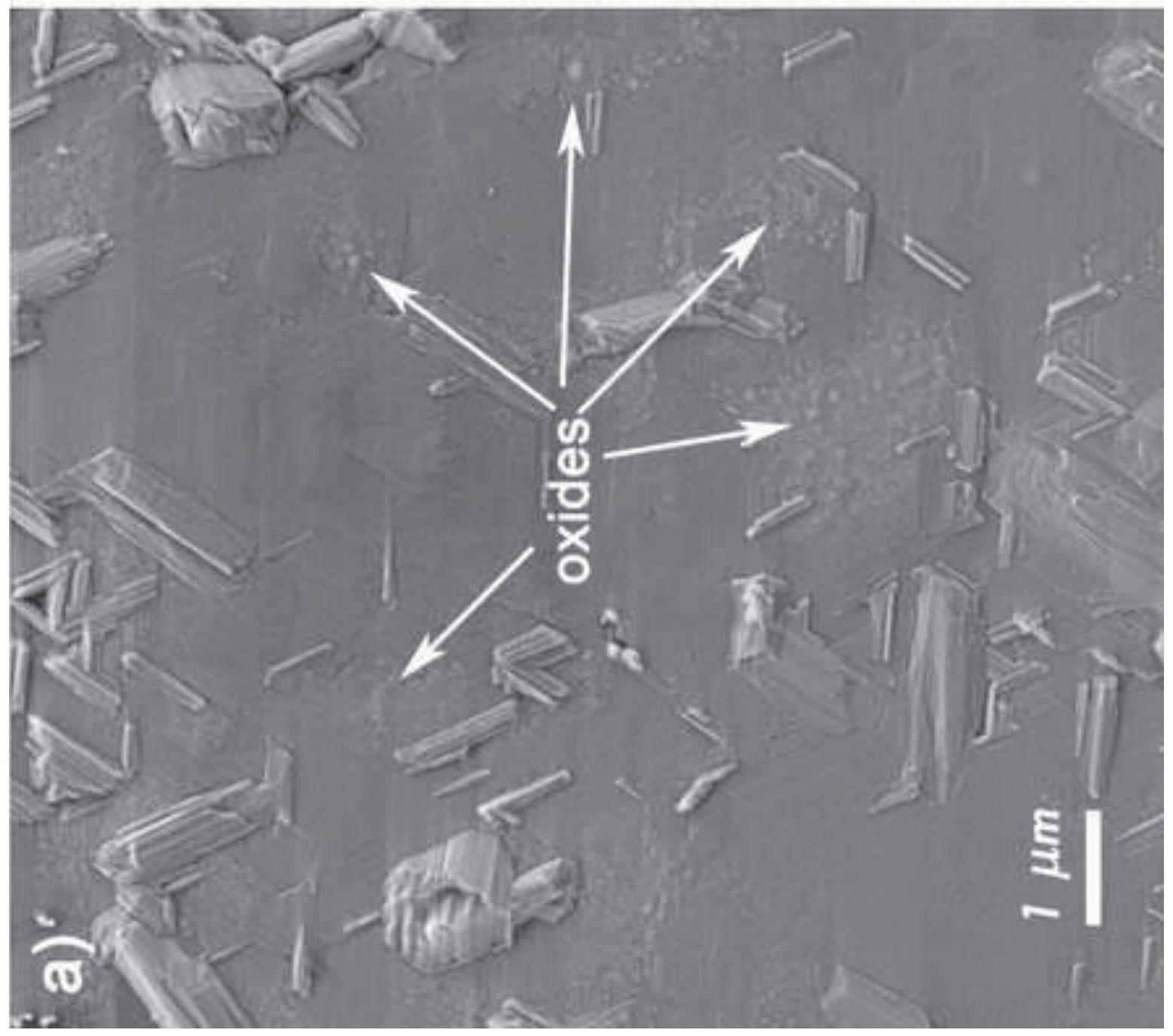




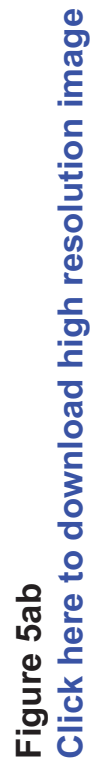

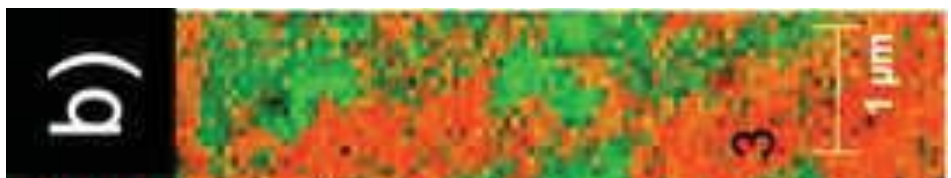

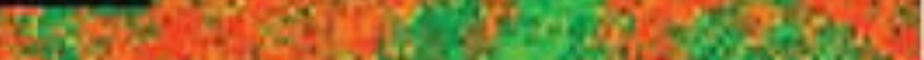

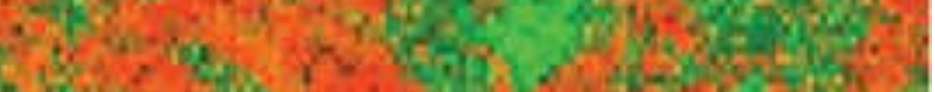

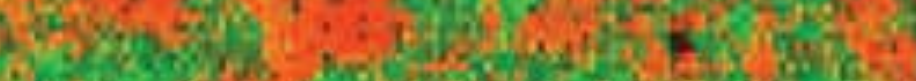

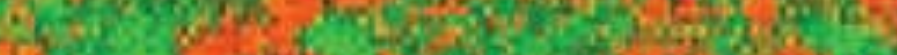

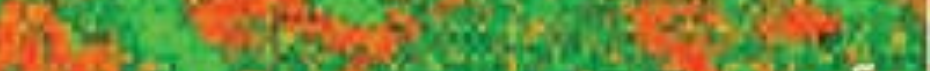

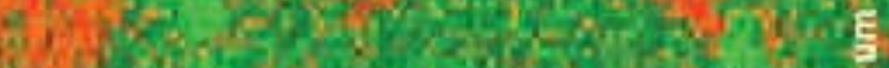

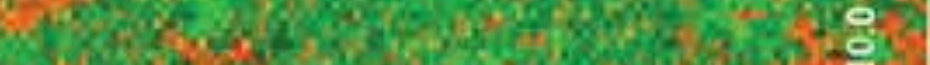

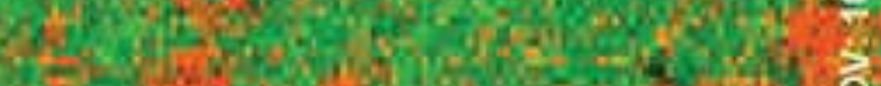

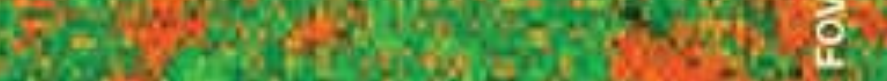

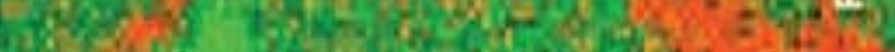

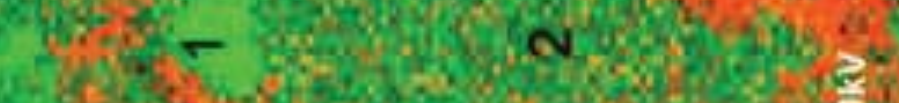

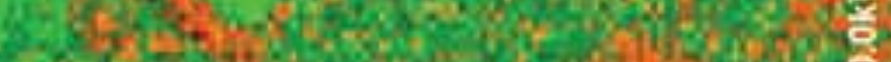

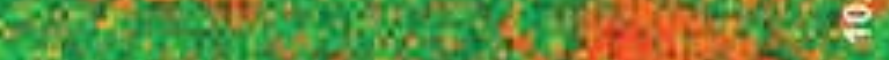

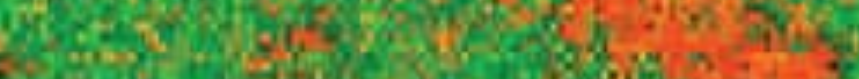

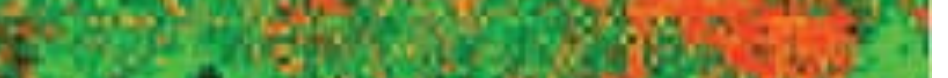

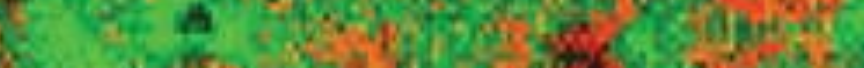

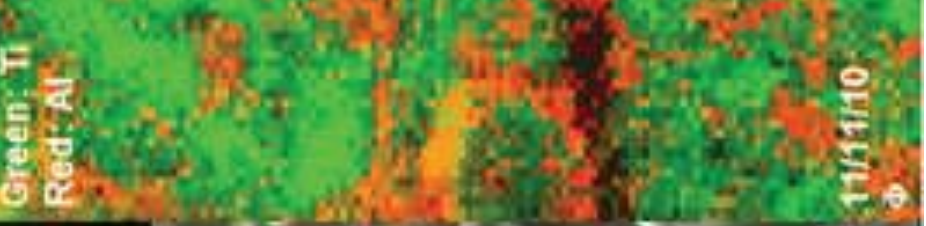
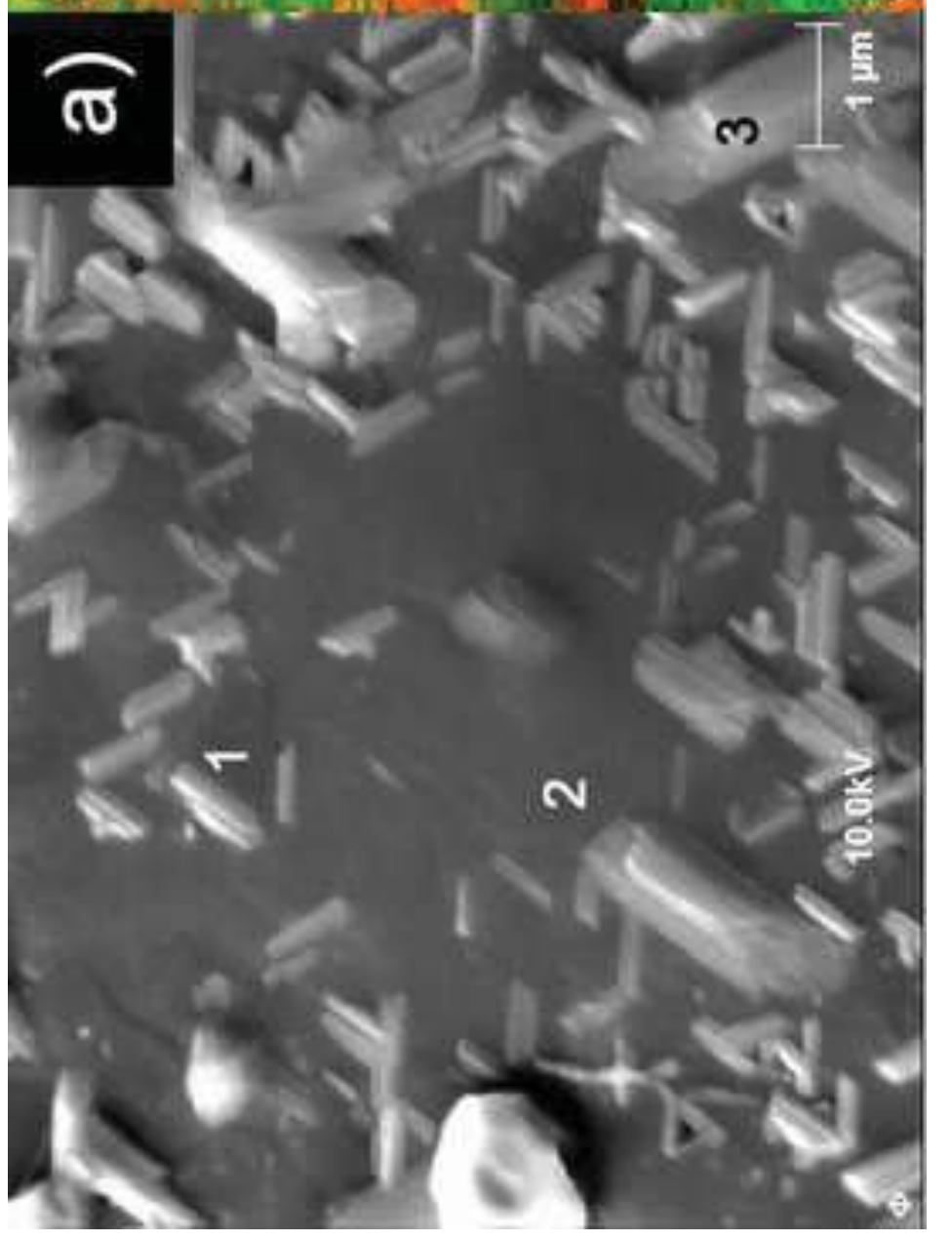
Figure 5c

Click here to download high resolution image
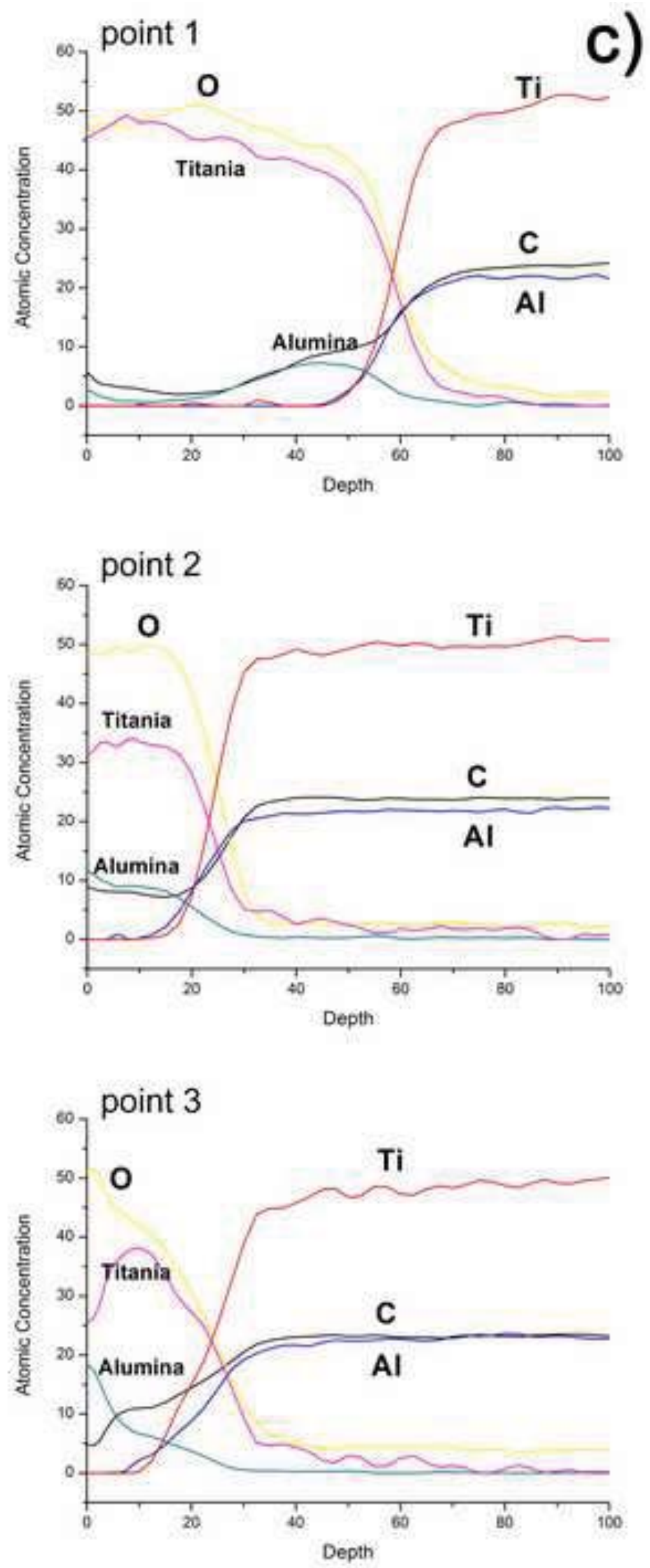

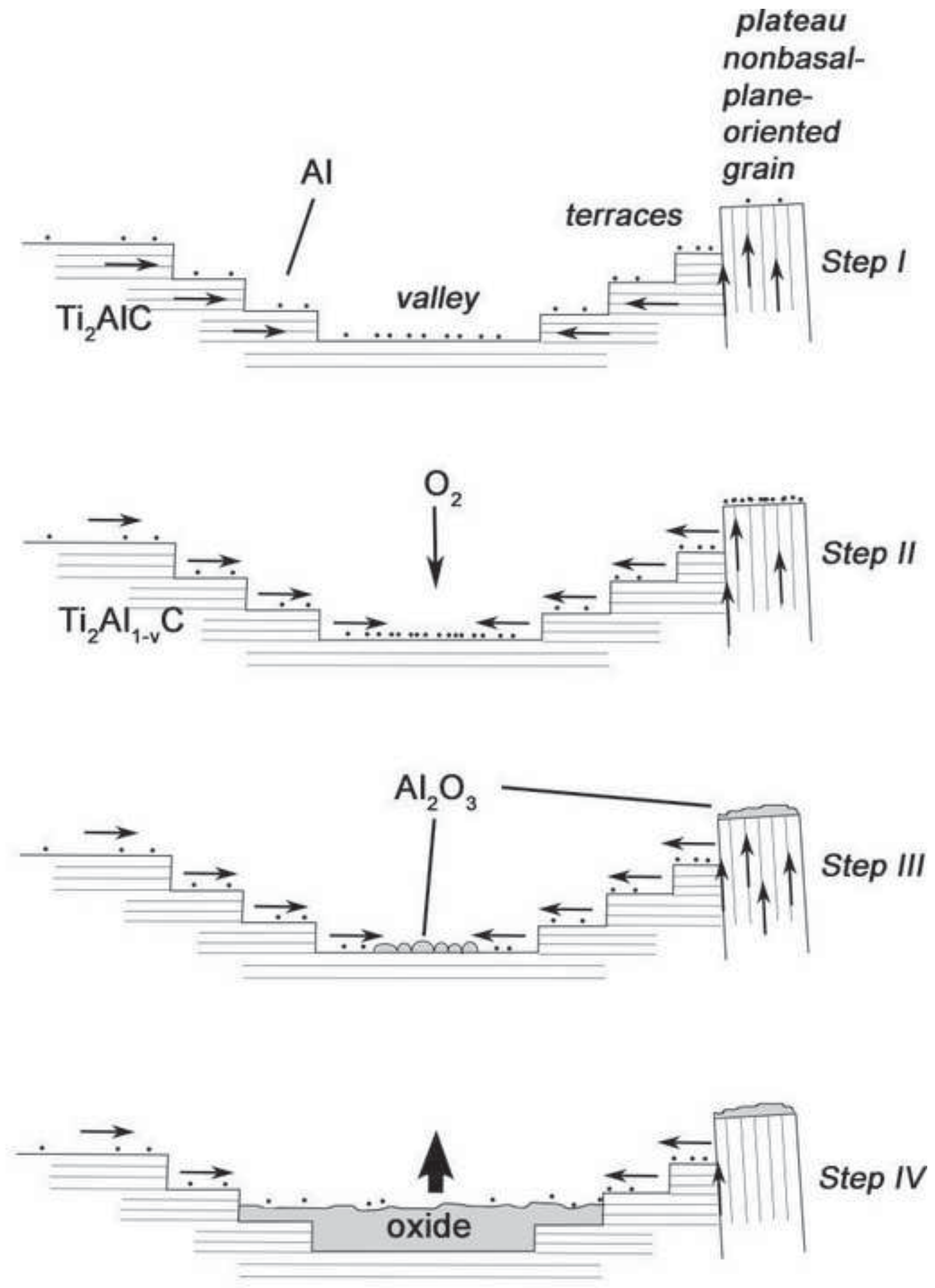


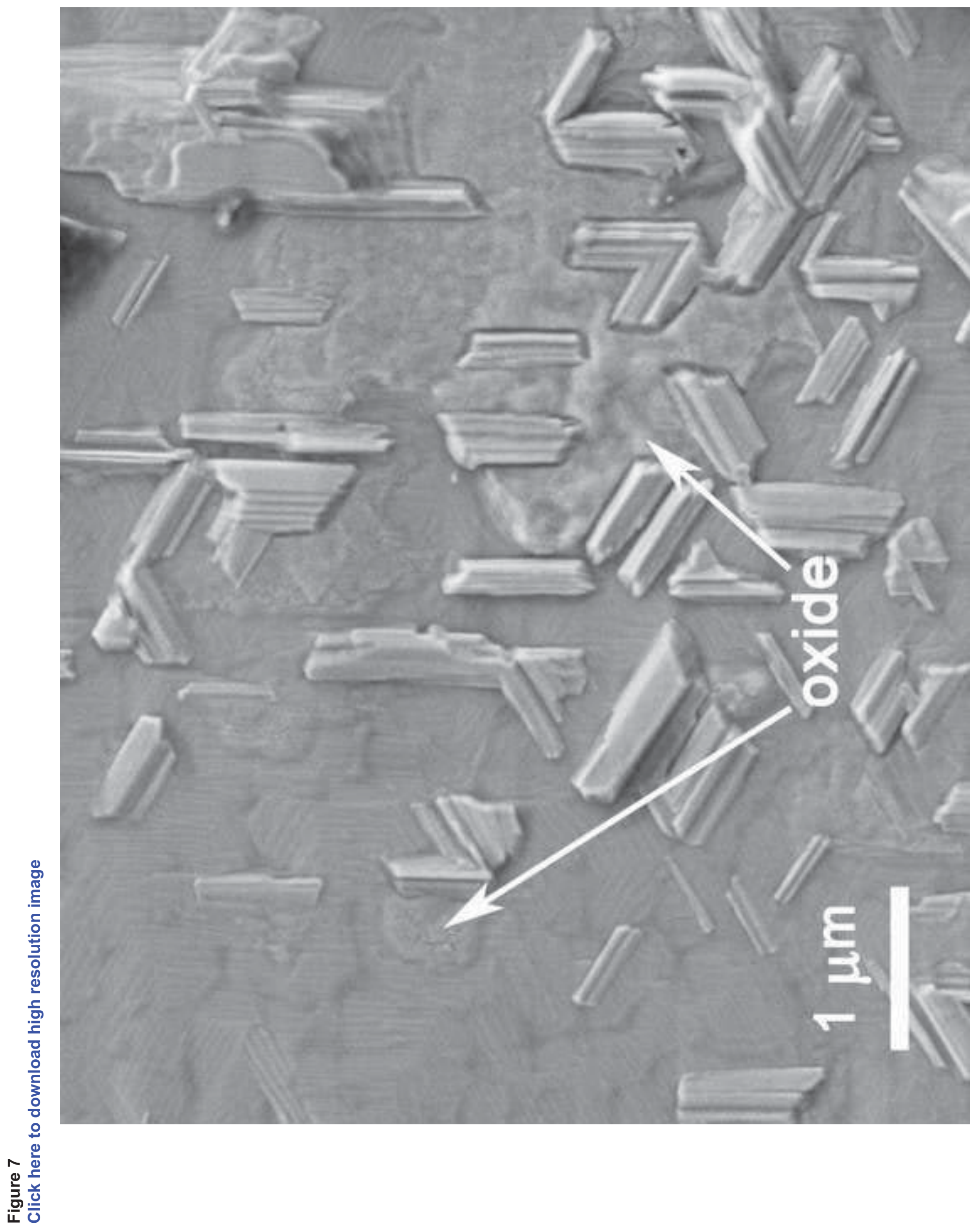

